\title{
OS CONTORNOS DO ESTADO PUNITIVO NO BRASIL
}

\section{Debora Regina Pastana"}

RESUMO: Este artigo reporta análises e conclusões formuladas a partir de observações sobre a Justiça Penal brasileira e que deram origem a tese intitulada "Justiça Penal no Brasil Atual: Discurso democrático prática autoritária”. O objetivo desta pesquisa foi refletir sobre a política criminal contemporânea, voltada à ampliação da repressão e ao uso contínuo do encarceramento. Tal política, implementada no Brasil logo após a abertura política ocorrida em 1985, ajusta-se ao projeto liberal também em curso no país e em praticamente todo o Ocidente capitalista.

\section{ESTADO PUNITIVO}

O tema central deste artigo é o investimento crescente no combate ao crime pelos atuais governos democráticos, que ao elegerem o sistema penal como a forma principal de controle social, contribuem para consolidar

\footnotetext{
* Bacharel em Direito pela Faculdade de História, Direito e Serviço Social da Universidade Estadual Paulista - UNESP. Bacharel em Direito e Doutora em Sociologia pela Universidade Estadual Paulista (UNESP).
}

RÉSUMÉ: This article reports the analyses and conclusions based on observations about the Brazilian Criminal Court, which originated the thesis under the title Criminal Court in Brazil Nowadays: Democratic Discourse Authoritarian Practice. The aim of this research is to reflect on the contemporary criminal policy, focussing on the increase in repression and the recurrent sentences to imprisonment. Such policy, implemented in Brazil in 1985, in the new era of democracy after a long period of dictatorship, is adjusted to the current liberal project in Brazil and in practically all the capitalist Occident.

a figura do "Estado Punitivo" também no Brasil.

Inserido nas recentes reflexões sociológicas de Loïc Wacquant (2001), David Garland (1995, 1999 e 2001), Nils Christie (2002) e Zygmunt Bauman (1999 e 2003), entre outros, esse tema é ainda desprezado pela comunidade acadêmica nacional. De fato, a expansão do controle penal brasileiro, nesse período democrático, carece de análises críticas associadas ao projeto liberal implementado atualmente em praticamente todo o ocidente capitalista. 
Nas duas últimas décadas do século XX as pesquisas em torno da criminalidade e do controle penal assumiram uma importância significativa perante as Universidades brasileiras. Essa importância se traduz na criação de inúmeros centros de estudos direcionados como, por exemplo, o Núcleo de Estudos da Violência (NEV) vinculado à Pró-Reitoria de Pesquisa da Universidade de São Paulo e o Centro de Estudos de Segurança e Cidadania (CESEC) da Universidade Candido Mendes.

As linhas de pesquisa desses centros buscam compreender as causas da criminalidade, além de realizarem projetos interdisciplinares visando ao aprimoramento da segurança pública no país. Também trabalham com a consolidação democrática nacional e com a efetivação dos direitos humanos no Brasil. Suas análises são variadas, contribuindo sobremaneira para a compreensão da criminalidade violenta no Brasil e para a ampliação do debate nacional sobre o controle social.

Contudo, apesar da relativa abundância de pesquisas retratando a violência criminal e seus temas correlatos, não se destaca no Brasil, como objeto específico de reflexão, o real significado das atuais posturas políticas sobre a punição. Os trabalhos relativos à segurança pública produzidos atualmente preocupam-se em discutir a eficácia, ou na maioria das vezes, a ineficácia, das instituições de controle. No entanto, mostrase oportuno, nesse momento obsessivo por segurança, questionar o que há de simbólico nas políticas penais atuais, para em grande medida associá-las ao projeto liberal em curso no país.
Ainsegurança social observada atualmente está cada vez mais ligada à violência criminal que, por sua vez, promove a base e o fortalecimento de uma cultura do medo. Essas questões - insegurança, violência, medo ganharam destaque no cotidiano das pessoas, na imprensa e mesmo nas Universidades em virtude da maior sensibilidade a elas e da aparente falta de controle por parte dos órgãos públicos.

Nesse novo cenário caracterizado pela cultura do medo (PASTANA, 2003), todo ato autoritário associado à segurança pública passa a ser visto como circunstancial e necessário. Assim, a dominação se dá diluindo a opressão em contextos instáveis e convencendo o oprimido de que ele está nessa situação não porque existem outros que o oprimem, mas porque vive em um ambiente hostil, onde o preço de sua segurança é a arbitrariedade e o autoritarismo.

Recentemente parte considerável da humanidade se vê inserida nessa tendência homogênea de obsessão securitária. $\mathrm{O}$ atual arranjo capitalista, de fato, generaliza-se quase que instantaneamente, atrelando o sucesso dos empreendimentos econômicos a nova face da política criminal.

Nesse novo arranjo político, o alarme social que se cria em torno da criminalidade acaba por provocar um generalizado desejo de punição, uma intensa busca de repressão e uma obsessão por segurança, ainda que simbólica. O controle penal passa a ser a "tábua de salvação" da sociedade e quanto maior for a sua dureza, mais satisfeita ela estará.

Esse controle absoluto é justamente o objeto central desta análise. Ao observarmos a atuação severa de nossas instituições de controle, particularmente a Justiça Penal, 
evidenciando o investimento cada vez maior do Estado brasileiro em ações repressivas e severas, podemos identificar os nítidos contornos de um "Estado Punitivo" que se ajustam às transformações econômicas, sociais e culturais já em curso nos últimos trinta anos nos países alinhados com o novo modelo capitalista de desenvolvimento.

É justamente essa associação que irá determinar um novo enfoque nas reflexões sobre o controle social nacional. De fato, é essencial poder identificar posturas ordinariamente punitivas que caracterizam o Estado policial e a conseqüente criminalização da miséria.

Mas o que torna uma política criminal unicamente "punitiva"? Para sermos mais exatos, e utilizando a perspectiva de Garland (1999), o que é que poderia justificar a descrição de uma trajetória da sociedade como "punitiva"?

A resposta é mais complexa do que parece. A 'punitividade', de fato, em parte é um juízo comparativo acerca da "severidade" das penas com relação às medidas penais precedentes, em parte depende dos objetivos e das justificativas das medidas penais, assim como também da maneira pela qual a medida é apresentada ao público. As novas medidas que aumentam o nível das penas, reduzem os tratamentos penitenciários, ou impõem condições mais restritivas aos delinqüentes colocados em liberdade condicional ou vigiada (...) podem ser consideradas 'punitivas', pois aumentam com relação a um ponto de referência anterior. (GARLAND, 1999, p. 60)

Assim, a maior parte das medidas penais recentes, engajadas em um modo de ação que expressa a necessidade constante de punição severa, traduzindo o sentimento público de intranqüilidade e insegurança e insistindo nos objetivos punitivos ou denunciadores; atestam, ao mesmo tempo, seu caráter inequivocamente punitivo.

Isso significa dizer que também no Brasil o "Estado Providência" sucumbe ante o "Estado Punitivo", no qual a assistência social dá lugar à atuação policial e carcerária. Esse novo paradigma altera a imagem das classes populares carentes de políticas sociais e os configura como inaptos, quando não simples parasitas do Estado. (SALLAS; GAUTO; ALVAREZ, 2006, p. 334). Segundo Wacquant (1999), essa transição entre o que ele denomina de "Estado Providência para o Estado-Penitência” destina-se "aos miseráveis, aos inúteis e aos insubordinados à ordem econômica e étnica que se segue ao abandono do compromisso fordistakeynesiano e à crise do gueto".

Volta-se para aqueles que compõem o subproletariado negro das grandes cidades, as frações desqualificadas da classe operária, aos que recusam o trabalho mal remunerado e se voltam para a economia informal da rua, cujo carro-chefe é o tráfico de drogas. (WACQUANT, 1999).

Ainda de acordo com o autor, propaga-se na Europa:

(...) um novo senso comum penal neoliberalsobre o qual vimos precedentemente como atravessou o Atlântico - pelo viés de uma rede de 'geradores de idéias' neoconservadoras e de seus aliados nos campos burocrático, jornalístico e acadêmico -, articulado em torno da maior repressão dos delitos menores e das simples infrações (com o slogan, tão sonoro como oco, da 'tolerância zero'), o agravamento das penas, a erosão da especificidade do tratamento da delinqüência juvenil, a vigilância em cima das populações e dos territórios considerados 'de risco', a desregulamentação da administração penitenciária e a redefinição da divisão do trabalho entre público e privado, em perfeita 
harmonia com o senso comum neoliberal em matéria econômica e social, que ele completa e conforta desdenhando qualquer consideração de ordem política e cívica para estender a linha de raciocínio economicista, o imperativo da responsabilidade individual - cujo avesso é a irresponsabilidade coletiva - e o dogma da eficiência do mercado ao domínio do crime e do castigo ( sic) (WACQUANT, 2001, p. 136).

Nesse sentido ficam cada vez mais evidentes as posturas autoritárias que, atreladas ao liberalismo contemporâneo, vêm sendo incorporadas pelo Estado brasileiro e articuladas, também, pela Justiça Penal. Isso significa dizer que o sistema penal brasileiro caminha atualmente menos para a consolidação democrática, e muito mais para a atuação simbólica, traduzida em aumento desproporcional de penas, maior encarceramento, supressão de direitos e garantias processuais, endurecimento da execução penal entre outras medidas igualmente severas. Tal sistema opera no sentido do "excesso de ordem", único capaz de tranqüilizar nossa atual sociedade de consumo hedonista e individualista.

\section{A JUSTIÇA PENAL COMO INSTRUMENTO SIMBÓLICO DE DOMINAÇÃO}

Realmente, o controle do crime nas democracias liberais do Ocidente pretendese absoluto nos dias atuais. Para tanto, os Estados, com "punho de ferro", organizam, de maneira autoritária e simbólica, as políticas penais implementadas para reforçar a função essencial do Estado burguês: "a garantia do sono tranqüilo do proprietário de Adam Smith e a redução do risco da morte violenta que atemorizava Thomas Hobbes" (PAIXÃO e BEATO, 1997, p. 2).
É manifesta, desde o século XIX, a conveniência da visão durkeimiana de controle para os interesses liberais. Sob essa ótica, o delito seria um enfrentamento direto entre indivíduo e coletividade e a punição, teria, portanto, a função de educar e reeducar para assegurar a coesão social. Atualmente, entretanto, tal serventia já não se sustenta. Mesmo o modelo disciplinar de Foucault (1987), que atribuiu à punição um caráter estratégico de dominação, assente no domínio da alma e na produção da docilidade e da domesticação, foi, de certa forma, suplantado.

Essa, aliás, é também uma faceta perversa da política criminal em curso, ou seja, o abandono do discurso jurídico ressocializador ${ }^{1}$ da pena permitindo, cada vez mais, a consideração da punição como simples "instrumento de encerramento de uma população considerada tanto desviante e perigosa como supérflua, no plano econômico" (WACQUANT, 2001, p. 98).

Durante uma boa parte do século XX, a expressão abertamente confessada do sentimento de vingança foi virtualmente tabu, pelo menos da parte dos representantes do Estado, mas, nesses últimos anos, tentativas explícitas de expressar a cólera e o ressentimento do público tornaram-se um tema recorrente da retórica que acompanha a legislação penal e a tomada de decisões. Os sentimentos da vítima, ou da família da vítima, ou um público temeroso, ultrajado, são agora constantemente invocados em apoio a novas leis e políticas penais. O castigo - no sentido de uma sanção significativa que apela para o sentimento do público - é uma vez mais um objetivo penal respeitável, abertamente reivindicado (GARLAND, 1999, p. 62).

\footnotetext{
${ }^{1}$ Figura criada no contexto iluminista para ilustrar a regeneração do infrator amansado pelo sistema jurídico burguês.
} 
Sobre esse aspecto, Garland (2001) também destaca que ao contrário da política criminal dos anos 50 ou 70, "que tinha como concepção básica a reforma e a intervenção social para prevenir e combater o crime", a atual forma de conceber as políticas de combate à criminalidade abandona a perspectiva humanista de reinserção do criminoso para focalizar a simples imposição de mecanismos de controle.

$\mathrm{O}$ crime e seu controle ingressam na agenda política e fortalecem o que se denomina de populismo, com as soluções fáceis, mas estimulando os receios e as inquietações da população. Como conclusão, o crime passou a ser visto não mais dentro de uma agenda de solidariedade e direitos, mas como quebra da ordem (SALLA; GAUTO; ALVAREZ, 2006).

Nessa nova ordem mundial "testemunhamos o retorno de práticas criminais centradas na figura do Estado Punitivo, caracterizado por práticas penais violentas e discriminatórias" (SOUZA, 2003).

Nesse contexto, a compaixão para com os delinqüentes é cada vez mais suplantada por uma preocupação mais exclusiva com as vítimas, e os políticos de todos os partidos vêem-se encorajados a tomar medidas firmes, não desprovidas de conotações populistas (GARLAND, 1999, p. 60).

Enfim, nas palavras de Garland (1999, p. 62), “a segregação punitiva - penas de longa duração em prisões 'sem frescuras' e uma existência estigmatizada, controlada de perto, para aqueles que são, finalmente, libertados - é cada vez mais a escolha que se impõe".

Esse controle social marcado pela violência punitiva contra as classes populares começa a despontar no Brasil nas duas últimas décadas do século XX, representando a exteriorização de uma ordem simbólica marcadamente liberal.

No Brasil, tal modelo político, centralizado na atuação punitiva, evidenciase na recorrência cada vez maior ao Direito Penal como solução em prima ratio de praticamente todos os conflitos sociais. Sua função, eminentemente simbólica, é atuar como mecanismo tranqüilizador da opinião pública que, hegemonicamente, busca proteção ao invés de cidadania.

Esse processo, apelidado também de “judicialização das relações sociais”, impõe, a partir da desconfiança, uma constante culpabilização das relações sociais. O Direito Penal, sob essa ótica, deve necessariamente prever e controlar toda e qualquer conduta social. "Se a Justiça é o novo palco da democracia, seu novo sentido, o Direito Penal, passa a ser a nova leitura das relações entre as pessoas cada vez mais estranhas umas às outras" (GARAPON, 2001, p.153).

De fato, como descreve Garapon (2001, p. 27-28):

(...) a invocação indiscriminada do Direito e dos direitos tem por efeito submeter ao controle do juiz aspectos inteiros da vida privada, antes fora de qualquer controle público. Pior, essa 'judicialização' acaba por impor uma versão penal a qualquer relação política, administrativa, comercial, social, familiar, até mesmo amorosa -, a partir de agora decifrada sob o ângulo binário e redutor da relação vítima/agressor.

Tal onipresença penal demanda reformas institucionais apresentadas como tentativas de dar conta do suposto aumento da criminalidade violenta e do sentimento de insegurança que se verifica no âmago da sociedade civil. A pressão da opinião pública, amplificada pelos meios de comunicação de 
massa, aponta para o aumento do controle penal, tendo como paradigma preferencial o fortalecimento e a severidade no trato com o crime e o encarceramento em massa das classes populares.

Conforme destaca Luis Antônio de Souza (2003):

(...) nos últimos trinta anos, houve profundas mudanças na forma como compreendemos o crime e a justiça criminal. $\mathrm{O}$ crime tornou-se um evento simbólico, um verdadeiro teste para a ordem social e para as políticas governamentais, um desafio para a sociedade civil, para a democracia e para os direitos humanos.

De fato, no Brasil, essa hegemonia do Estado Punitivo, embora revestida da aura democrática, representa, ao contrário, uma violência institucional ilegítima, diluída na banalização da desigualdade e reforçada na seletividade da punição e conseqüente aniquilação do transgressor.

Atualmente pode-se dizer, sem receio, que vivemos sob a mais violenta intervenção do Estado na vida dos cidadãos, materializada através de uma dominação simbólica articulada pelo medo e por uma democracia fraturada, assente apenas no plano formal. "Por não sabermos mais distinguir a violência legítima da ilegítima, somos incapazes de determinar a dívida, quer dizer, o preço do ingresso na vida em comum" (GARAPON, 2001, p.53).

Essa ordem estrategicamente confusa é acompanhada de uma potencialidade paradoxal. A violência institucional pretende ser sua própria negação, conduzindo a uma ideologia da "tranqüilização da vida social". No entanto, dada sua potencialidade, essa violência pede certo grau de legitimação só alcançável através do pânico.
Assim, o que se observa é que essa maior intervenção penal ocorre pelo interesse de perpetuar uma forma de dominação autoritária que só subsiste com a degradação da sociabilidade e a diminuição do exercício cívico. Verifica-se que o atual Estado burguês, para manter legítimo o uso da força, aperfeiçoa sua dominação simbolicamente, vale dizer, através da consolidação de uma cultura aterrorizante.

Conforme destacamos, no Brasil, as respostas à criminalidade consistem, em sua grande maioria, em penas severas, traduzidas na ausência do respeito às garantias constitucionais e no recurso amplo ao encarceramento. Nessa linha, nossos governos democráticos contemporâneos freqüentemente adotam uma posição punitiva que visa reafirmar a aptidão do Estado em punir e controlar a criminalidade.

Como exemplo, podemos citar a política de encarceramento no Brasil que, aumentando vertiginosamente nos últimos anos, ultrapassou, no ano de 2006, a marca dos 401.000 presos. O sistema penitenciário brasileiro, por sua vez, ocupa de acordo com dados do Departamento Penitenciário Nacional, ${ }^{2} 1051$ estabelecimentos com um total de 236.088 vagas (homens: $223.164 \mathrm{e}$ mulheres: 12.924), e, portanto, déficit de mais de 166.000 vagas.

Tal aumento, dada à sua característica liberal, é, de fato, uma realidade em muitos países ocidentais. Loïc Wacquant (2001b), ao analisar o inchaço das penitenciárias norte-americanas, comentou que "se

\footnotetext{
${ }^{2}$ Dados disponibilizados em dezembro de 2006. Disponível em http://www.mj.gov.br/depen. Acessado em 20 de julho de 2007.
} 
fosse uma cidade, o sistema penitenciário americano seria a quarta metrópole do país”. Esse encarceramento em massa reflete, na realidade, uma estrutura de dominação contemporânea que mascara uma exclusão capitalista ainda mais perversa, o isolamento e a neutralização dos miseráveis em praticamente todo o globo.

De fato, como bem assevera Nils Christie (2002, p. 93), "são as decisões político-culturais que determinam a estatística carcerária e não o nível ou evolução da criminalidade". O maior encarceramento não tem, portanto, relação direta com o aumento das práticas criminosas, mas sim com o aumento dos miseráveis, totalmente excluídos do universo do trabalho.

O fato é que o Estado brasileiro descobriu que criminalizar é expediente fácil para garantir o sucesso das políticas liberais adotadas. Diante do medo hegemônico crescente, muitas vezes amplificado pelos meios de comunicação de massa, o Judiciário cumpre sua função orgânica de proteger a elite, agindo com rigor no combate ao crime proveniente das classes populares. Em um ciclo vicioso, o campo jurídico passa a associar a eficiência à repressão. A legitimidade, portanto, está na atuação autoritária.

\section{CRIMINALIZAÇÃO DA MISÉRIA}

Essa penalização liberal, denominada por Wacquant (2001a, p. 10) "ditadura sobre os pobres", procura reprimir com severidade "as desordens suscitadas pela desregulamentação da economia, pela dessocialização do trabalho assalariado e pela pauperização relativa e absoluta de amplos contingentes do proletariado urbano, aumentando os meios, a amplitude e a intensidade da intervenção do aparelho policial e judiciário". A esse respeito, Bauman (1998, p. 53) adverte que nesse novo contexto, marcado pela intensificação das relações de consumo, "as classes perigosas são assim redefinidas como classes de criminosos."

Segundo estudos realizados pelo Ilanud (JACOBS, 2004), “o perfil para o presidiário brasileiro é de alguém majoritariamente pobre, do sexo masculino, de até 35 anos, com baixa escolaridade e baixa capacidade de inserção no mercado de trabalho". Isso demonstra claramente que também no Brasil se opera a criminalização da miséria apontada por Wacquant, na Europa.

Aqui no Brasil tal fato já havia sido abordado por Ruben Oliven no começo dos anos oitenta. No artigo Chame o ladrão: As vítimas da violência no Brasil, alertava para o fato de que os grupos dominados eram, freqüentemente, muito mais vítimas que responsáveis pela violência criminal em nossas cidades, no entanto eram os mais perseguidos pela Justiça Penal e o que mais recebiam punição (OLIVEN, 1981, p. 28).

Mesmo Bauman (1999) atenta para o fato de que a punição para as ações mais prováveis de serem cometidas por pessoas excluídas da ordem atual, pelos "pobres diabos tiranizados", tem a melhor chance de aparecer no código criminal.

Roubar os recursos de nações inteiras é chamado de 'promoção do livre comércio'; roubar famílias e comunidades inteiras de seu meio de subsistência é chamado 'enxugamento' ou simplesmente 'racionalização'. Nenhum desses feitos jamais foi incluído entre os atos criminosos passíveis de punição. (...) Só em casos raros e extremos os 'crimes empresariais' são levados aos tribunais e 
aos olhos do público. Fraudadores do fisco e autores de desfalques têm uma oportunidade infinitamente maior de acordo fora dos tribunais do que os batedores de carteira ou assaltantes (BAUMAN, 1999, p 131-132).

“É provável que um só golpe sofisticado, arquitetado por criminosos de 'colarinho branco', renda prejuízo maior para a sociedade e para o Estado do que a soma de todos os roubos e furtos cometidos pelos miseráveis que se embrutecem nos cárceres" (ATHAYDE, [et.al.], 2005, p. 188). Entretanto, os focos usuais da nossa Justiça Penal ainda são os flagrantes do estigma social, aqueles que põem em risco a ordem classista e o distanciamento seguro.

Todos esses fatores considerados em conjunto convergem para a compreensão burguesa que identifica a prática do crime somente pelos "desclassificados", o que resulta praticamente na criminalização da pobreza (BAUMAN, 1999, p. 134).

Essa massa excluída do trabalho e, conseqüentemente, do consumo, fica submetida a um gigantesco sistema penal responsável não mais por disciplinar os desviantes, mas sim por conter o refugo social produzido pelo recente contexto liberal. Ironicamente Wacquant (ap. BATISTA, 2003a) considera tal fenômeno como "uma espécie de único programa público habitacional do capitalismo tardio".

Reforçando essa tese, Bauman (1999, p. 128-129) assevera que atualmente, “os governos detêm pouco mais que o papel de distritos policiais super-dimensionados", varrendo os mendigos, perturbadores e ladrões das ruas, e garantindo, com a firmeza dos muros das prisões, a “confiança dos investidores”.
Fazer o melhor policial possível é a melhor coisa (talvez a única) que o Estado possa fazer para atrair o capital nômade a investir no bem-estar dos seus súditos; e assim o caminho mais curto para a prosperidade econômica da nação e, supõe-se, para a sensação de 'bemestar' dos eleitores, é a da pública exibição de competência policial e destreza do Estado (BAUMAN 1999, p. 129).

Como não poderia deixar de ser, os valores expressos nessa lógica liberal delimitam o âmbito de atuação da nossa Justiça Penal por meio de demandas sobre o sistema que devem absurdamente articular dois planos: de um lado, a atividade se dá num contexto democrático; de outro, sua eficiência é julgada pelo grau de arbitrariedade e severidade com que responde ao delito.

Nosso próprio ordenamento penal está impregnado de valores burgueses que refletem exatamente essa dominação autoritária e excludente. Há em nossas leis profundos ataques aos princípios democráticos $\mathrm{e}$ que representam formas de desrespeito à cidadania e à dignidade humana. Composto, em sua maioria, por penas que importam encarceramentos longos e degradantes, inclusive para menores, e que são associados em grande medida aos crimes tradicionais, nosso corpo de leis está longe de representar um Estado democrático. Ainda assim, é considerado pelo próprio "operador do Direito" como inócuo, pois ainda não aniquila totalmente o infrator.

Segundo o promotor de justiça Carlos Edurado Fonseca Da Matta, ${ }^{3}$ defensor desta tese:

${ }^{3}$ Promotor da $3^{\text {a }}$ Procuradoria de Justiça do Ministério Público de São Paulo, em entrevista para a Revista Super Interessante de abril de 2002, p. 45, edição especial com tema segurança. 
No direito penal realmente científico, o importante é conter o criminoso. A idéia de reabilitação é uma falácia. O papel do Direito Penal é proteger a sociedade e, por isso, latrocidas, estupradores e seqüestradores têm que ficar presos por um longo período para que não possam cometer novos crimes.

Isso explica, em parte, o desinteresse de muitos juristas em saber o que acontece no interior das prisões brasileiras, como se os muros das unidades prisionais conseguissem estancar, definitivamente, a perversidade do controle social empregado. Ao se eximir da responsabilidade de fiscalizar as condições carcerárias e mantendo a cultura de só punir com a cadeia, o Judiciário implementa, com o encarceramento desenfreado e cruel, as bases para a consolidação do Estado Punitivo no Brasil.

Tal violência institucional conduzida por essa ideologia de "tranqüilização da vida social" é, efetivamente, o estratagema encontrado por uma classe para camuflar a desigualdade e sufocar os anseios daqueles que contrastam com seus interesses.

Para piorar, a sobrevivência da frase getulista: "aos amigos tudo e aos inimigos o peso da lei", continua a revelar a desigualdade e, principalmente, o uso arbitrário da norma. A lei, portanto, é muitas vezes usada apenas contra as classes populares, para garantir a dominação perpetrada.

Nesse momento, é importante observar que a ética liberal ainda insiste na velha máxima de que todos nós somos seres livres e racionais, tomando nossas decisões a partir de um amplo espectro de opções. "Para pequena e ampla burguesia isso significa dedicação ao trabalho, ao lazer, às compras e à prosperidade, sem culpa, pois estão liberadas pela crença de que os indivíduos são livres e independentes, cada qual responsável por seus atos e tragédias" (SOUZA, 2003). As classes populares também seriam livres para fazer suas escolhas, e dentro dessa perspectiva, o crime também é visto como uma escolha racional. Essa é inclusive a opinião externada pelo juiz Luiz Ambra do TACRIM $^{4}$ de São Paulo:

Continuo entendendo o que sempre entendi, quando da passagem do fechado para o semiaberto: não há vaga? O criminoso que se dane. (...) Simples aplicação da teoria do 'risco profissional', bem exposta pelo eminente juiz Corrêa de Moraes, desta Câmara. Ao adotar o crime como profissão, em outras palavras, como em qualquer atividade sujeita-se o delinqüente a riscos que lhe são inerentes. Dela fazem parte, em algumas das 'empreitas' não ser bem sucedido, levar um tiro e morrer, ser preso, na cadeia não receber o tratamento 'à altura' de que se julgar merecedor, passar à promiscuidade com outros detentos, por eles ser seviciado e estar sujeito a abusos sexuais (TACRIM/SP - HC nº. 402.314/6 - Capital Voto n..$^{\circ}$ 9388).

Tal premissa permite aumentar a atuação da Justiça Penal e a severidade das punições aplicadas, camuflando a seletividade do sistema nas tão conhecidas ficções liberais de igualdade de oportunidade e liberdade de escolha.

Acreditar que o crime é uma decisão, dá apoio à ficção necessária da economia de mercado segundo a qual a prosperidade e a pobreza são conquistas de indivíduos, não são condicionantes de raças, classes ou gêneros, bem como nenhuma pessoa é responsável pela dificuldade de outras ou obrigada a confrontar deficiências estruturais no sistema. (SOUZA, 2003).

Ideologia mais do que consolidada, essa postura liberal perante o delito, além de

\footnotetext{
${ }^{4}$ Tribunal de Alçada Criminal.
} 
radicalizar o controle penal, intensificando a atuação dos órgãos de controle, também restringe a liberdade e o exercício cívico das classes populares.

Nas palavras de Nilo Batista (2003a):

(...) o empreendimento neoliberal, capaz de destruir parques industriais nacionais inteiros, com conseqüentes taxas alarmantes de desemprego; capaz de 'flexibilizar' direitos trabalhistas, com a inevitável criação de subempregos; capaz de, tomando a insegurança econômica como princípio doutrinário, restringir aposentadoria e auxílios previdenciários (...); esse empreendimento neoliberal precisa de um poder punitivo onipresente e capilarizado, para o controle penal dos contingentes humanos que ele mesmo marginaliza. (sic)

Certamente, a essa altura não cabe mais a ingenuidade de supor que o fortalecimento dessa postura penal não passa pela conjuntura econômica e política que vivenciamos. Ao contrário, em tempos de Estado Mínimo, parece que "a única política pública que verdadeiramente se manteve é a política criminal" (BATISTA, 2003a).

Bem próximo ao dogma da pena encontramos o dogma da criminalização provedora. Agora, na forma de uma deusa alada onipresente, vemos uma criminalização que resolve problemas, que influencia a alma dos seres humanos para que eles pratiquem certas ações e se abstenham de outras (...). A criminalização, assim entendida, é mais do que um ato de governo do príncipe no Estado mínimo: é muitas vezes o único ato de governo do qual dispõe ele para administrar, da maneira mais drástica, os próprios conflitos que criou. Prover mediante criminalização é quase a única medida de que o governante neoliberal dispõe. (sic) (BATISTA, 2003b, p. 4)

Enfim, em tempos liberais como o atual, o que caracteriza a atuação penal é a noção de emergência, entendida como um momento excepcional a exigir "uma resposta pronta e imediata, que deve durar enquanto o estado emergencial perdure." (BECK, 2004, p. 95). Essa noção de emergência, alimentada pelo medo social constante e estrategicamente introjetado, transforma os conflitos em ameaças e torna fácil desviar o cerne dos problemas, que não é de natureza conjuntural, mas social. Sob essa lógica, o Estado Punitivo busca sua legitimidade exatamente lançando mão dos mecanismos de punição capazes de gerenciar a pobreza e disseminar o medo.

\section{DEMOCRACIA AUTORITÁRIA: TAMBÉM UM PARADOXO NACIONAL}

Aderindo a esse projeto, o Brasil adotou o que Lamounier e Souza (2006, p. 48) denominaram "democracia tutelada". Para orquestrar o desmanche estatal sem contestações políticas capazes de reverter o processo, o Estado "testa até o limite o regime democrático, mas não o suprime em termos estritamente legais" (LAMOUNIER e SOUZA, 2006, p. 48). Além disso, todos os problemas resultantes dessa desregulamentação, como a precarização das relações de trabalho, o desemprego e a dificuldade de acesso aos serviços essenciais, que levam invariavelmente ao aumento da criminalidade, não são solucionados, apenas a consequiência se torna questão emergencial. Assim, observa-se o endurecimento das medidas repressivas "justificado pela retórica de 'defesa interna e externa' da nação", para silenciar os críticos (LAMOUNIER e SOUZA 2006, p. 48). 
Travestida de pilar da democracia, que sustenta a liberdade e a propriedade privada, a Justiça Penal brasileira articula sua nova gramática convivendo sempre, e cada vez mais intensamente, com o perpétuo sentimento de impunidade. A punição exemplar e severa, simbolizada no longo encarceramento, une-se às exigências liberais traduzidas no binômio: democracia - liberdade individual.

Para piorar os meios de comunicação de massa reforçam cotidianamente a necessidade da maior intervenção penal. Ao explorarem economicamente o problema da violência criminal acabam por legitimar o recrudescimento penal autoritário responsável por expandir o quadro de exclusão social atual. Sobre o tema Vera Batista (2001, p. 04) destaca que as campanhas maciças de pânico social veiculada na imprensa, permitiram um avanço sem precedentes na internalização do autoritarismo. Segundo a socióloga, pode-se afirmar sem medo de errar "que a ideologia do extermínio é hoje muito mais massiva e introjetada do que nos anos imediatamente posteriores ao fim da ditadura".

Em virtude desse viés altamente controlador, no que se refere aos conflitos sociais, cria-se um circulo vicioso que produz um aumento exponencial da insegurança da população frente à violência e que legitima o aumento da repressão ainda que de forma autoritária. Sem alterar os ritos democráticos o controle se expande mediante a edição interminável de leis penais incriminando novas condutas e do tratamento cada vez mais severo destinado ao infrator.

Esse controle violento e discriminatório, de forma ambígua, passa a ser simultaneamente bombeiro e incendiário. No mesmo movimento ele incentiva a desconfiança, desqualifica qualquer solução que não seja a jurídica e apresenta seu único remédio: mais segregação e restrição de liberdade. Esse modelo tem como conseqüência imediata aumentar o número de detentos em proporções inquietantes, fenômeno percebido não só no Brasil mas em várias democracias contemporâneas.

Confirmando tal reflexão, um balanço realizado pela CENAPA, ${ }^{5}$ órgão vinculado ao Ministério da Justiça, atestou, no ano de 2003, que as penas alternativas, ${ }^{6}$ recomendadas para crimes de pequena e média gravidade, beneficiavam apenas $8,7 \%$ dos infratores do país. ${ }^{7}$ Em alguns Estados, no entanto, não se chegava nem a esse percentual: em São Paulo, por exemplo, as penas beneficiavam apenas $1,3 \%$ dos infratores.

Não existia, na época, (e não existe ainda hoje), um estudo mostrando quantos presos poderiam estar fora do cárcere cumprindo essas penas, no entanto, segundo Maria Eli Bruno,${ }^{8}$ coordenadora do CENAPA paulista, cerca de $10 \%$ dos presos de São Paulo

\footnotetext{
${ }^{5}$ Central Nacional de Apoio e Acompanhamento às Penas e Medidas Alternativas.

${ }^{6}$ Uma mudança na legislação, feita em 1998 pela Lei n. ${ }^{\circ} 9.714 / 98$, passou a permitir que os condenados a até quatro anos de prisão, cujo crime não tenha envolvido violência, tenham a pena de prisão convertida para uma punição alternativa. Entre elas estão as restritivas de direitos, as de prestação de serviços à comunidade e as pecuniárias.

${ }^{7}$ De acordo com o juiz Ali Mazloum, na época lotado na $7^{\text {a }}$ vara federal criminal em São Paulo, cerca de $50 \%$ das ações penais na esfera federal permitiam que fossem aplicadas as penas alternativas. $\mathrm{O}$ juiz estimava também que, na esfera estadual, esse percentual poderia chegar a $60 \%$. In. Jornal Folha de São Paulo. Edição de $16 / 08 / 2003$.

${ }^{8}$ In: Jornal Folha de São Paulo. Edição de 16/08/2003.
} 
poderiam, no ano de 2003, estar cumprindo outro tipo de pena.

Dados $^{9}$ da Secretaria de Administração Penitenciária de São Paulo atestavam também, em 2004, que muitos criminosos eram condenados pelos juízes a regimes mais severos de cumprimento de pena do que os previstos na lei. Naquele momento, de cada dez presos condenados por roubo no Estado, sete deles teriam que cumprir penas fixadas próximas ao mínimo legal e seriam réus primários. Em tese, portanto, atendiam às primeiras exigências impostas para a concessão do regime semi-aberto. Na prática, contudo, os números eram bem diferentes. A análise identificava 24.619 condenados por roubo cumprindo pena em regime fechado no Estado (23,56\% do total de 104.488 presos, para 79.629 vagas). Roubo, que não é crime hediondo, não exige, portanto, a condenação direta ao regime fechado, no entanto, só 4.519 (18\%) estavam em semi-aberto.

Esses índices mostram que nossa Justiça Penal está impregnada da idéia de encarcerar, mesmo que isso não tenha reflexos na diminuição da criminalidade. Ao contrário, nosso sistema prisional, tradicionalmente degradante e estigmatizante, serve mais como ponto de reunião, organização e difusão da criminalidade em larga escala.

Durante a execução da pena o endurecimento também se manifesta, ainda que em dissonância com a legislação. Essa foi a constatação da pesquisa realizada pela Fundação Seade, no ano de 2002, no universo dos processos de execução criminal na Vara das Execuções Criminais da capital paulista. Segundo a pesquisa:

\footnotetext{
${ }^{9}$ Veiculados no Jornal Folha de São Paulo. Edição de $01 / 09 / 2004$.
}

Com referência à progressão de regime, o primeiro resultado obtido indica que $22,1 \%$ de presos obtiveram a progressão de regime (com margem de erro 4\%). Deste modo, apenas uma pequena parte da população carcerária logra cumprir sua pena de modo progressivo, muito embora a progressividade seja o modelo geral adotado pela LEP e pela Constituição Federal (...). Outra informação reveladora é que 72,5\% das pessoas que obtiveram a progressão haviam cumprido mais de um terço da pena. Por esse dado infere-se que, da pequena parte dos presos que obtém a progressão de regime, a maioria só a alcança com o cumprimento do prazo muito acima do legal (um sexto), o que demonstra que este não é balizador das decisões dos juízes. (...) Em relação ao livramento condicional, observou-se que $8 \%$ de presos obtiveram este benefício (margem de erro 3\%). (...) Esse dado aponta para uma parcela muito pouco significativa da massa carcerária que realmente chega a alcançar o benefício. Note-se que seu percentual é ainda inferior ao dos que obtêm a progressão de regime. (TEIXEIRA \& BORDINI, 2004)

Pelo que se observa, a Justiça Penal, mesmo durante a execução da pena, opera de forma autoritária e excludente, ao suprimir ao máximo os direitos previstos em lei para os condenados, adotando uma postura altamente repressiva, revelada pelos ínfimos percentuais de benefícios ${ }^{10}$ concedidos. Orientado pela via

\footnotetext{
${ }^{10}$ Entre os benefícios prisionais estão as progressões de regime, o livramento condicional, a autorização de saída temporária, entre outros, todos previstos na Lei de Execução Penal. (Lei n. ${ }^{\circ}$ 7210/84). A legislação penal determina diferentes regimes de cumprimento das penas: fechado, semi-aberto e aberto. Nos dois últimos, admite-se a possibilidade de o preso trabalhar fora dos muros e visitar a família regularmente. O regime inicial de cumprimento de pena é determinado pelo tempo de condenação e pela reincidência ou não do condenado. Ao longo de sua pena o preso pode ser beneficiado com a mudança de um regime para outro, considerando-se, para tanto, o tempo de pena já cumprido e a situação disciplinar. Ainda de acordo com a legislação, o regime fechado deve ser cumprido em Penitenciárias, o regime semi-aberto em Colônias agrícolas ou industriais e o regime aberto em Casas de Albergado. O livramento
} 
da segregação penal, está assumindo nosso Judiciário a tese hegemônica que conclama a maior punição como meio legítimo de controle social. Agindo assim, nossos juízes não só promovem o confinamento violento das classes populares como contribuem para o "reforço de atitudes de cinismo e descrença frente à competência de modelos democráticos de resolução de conflitos" (PAIXÃO \& BEATO, 1997, p. 2).

Como se observa, são nítidos os efeitos simbólicos, promocionais e excessivamente intervencionistas da política penal brasileira nesse momento atual. Fundamentada na difusão do medo e na promessa de tranqüilidade social a qualquer custo, o Estado brasileiro adota, explicitamente, medidas repressivas severas, ilegais e desumanas.

Entre nós, portanto, também é correta a afirmação de que as políticas penais adotadas recentemente caminham para a consolidação do Estado Punitivo, uma vez que estão voltadas para a defesa da lei e da ordem liberal, materializadas na violência institucional contra as classes populares. Nesse sentido, nossa política criminal é

condicional é a antecipação provisória da liberdade do condenado pelo juiz da Vara das Execuções Criminais, quando presentes determinados requisitos legais. O sentenciado fica sujeito a certas obrigações. Entre os requisitos indispensáveis, está o cumprimento de mais de $1 / 3$ da pena se o condenado não for reincidente em crime doloso e antecedentes favoráveis. As saídas temporárias consistem em permissões judiciais para presos de boa conduta carcerária que cumprem pena em regime semiaberto O próprio Diretor geral do Presídio encaminha ao juiz a relação dos presos que têm direito à saída temporária. A Lei de Execução prevê saída temporária para visitar a família, que pode ser concedida cinco vezes ao ano. Cada saída poderá durar até sete dias corridos. As saídas são regulamentadas e concedidas nas seguintes datas: Natal/Ano Novo; Páscoa; Dia das Mães; Dia dos Pais e Finados. também o retrato da adesão às premissas liberais refletidas no excessivo, desumano e desigual tratamento penal.

Assim, é necessário aprofundar essa discussão explicitando os atuais contornos do Estado Punitivo no Brasil, ou seja, demarcando as políticas penais brasileiras (as implementadas e as idealizadas) que se ajustam as amplas transformações econômicas e sociais que marcam o nosso momento político contemporâneo.

Medidas de endurecimento punitivo já introduzidas em nosso ordenamento como a lei dos crimes hediondos (Lei n. ${ }^{\circ}$ 8072/90) e, mais recentemente, a lei Maria da Penha (Lei n. ${ }^{\circ} 11340 / 06$ ); e mesmo medidas de recrudescimento na execução penal como o Regime Disciplinar Diferenciado - RDD (instituído pela Lei n. ${ }^{\circ} 10.792 / 03$ ) refletem o modo como a política atual contribui para criminalizar os problemas sociais causados pelo sistema econômico em vigor.

É nesse contexto que também proliferam os projetos de lei que visam à ampliação do Estado Punitivo no Brasil. Apelidado de "Pacotão do Pânico", o conjunto de projetos sobre o endurecimento penal em tramitação no Congresso Nacional prevê, entre outras medidas, a inclusão de vários crimes na categoria dos hediondos com o conseqüente aumento de pena e redução dos benefícios penais; o aumento do período máximo de prisão que atualmente é de 30 anos; o aumento de pena para infratores adultos que cometerem delitos com o auxílio de menores; a redução de prazos prescricionais para determinados delitos e a alteração no tempo máximo de internação de menores infratores dos três anos atuais para um prazo maior que poderia chegar a 20 anos. 
Nessa linha, de todos os projetos em tramitação o mais evidente, no momento, é, sem dúvida, o projeto de emenda constitucional que trata da redução da idade penal. O modo sensacionalista com o qual os meios de comunicação noticiaram o assassinato do menino carioca João Hélio acabou por ressuscitar a discussão sobre a redução da idade penal no país. Mesmo a intelectualidade, representada pelo filósofo Renato Janine Ribeiro, ${ }^{11}$ passou a clamar por "suplícios medievais" e pena de morte como punição para os criminosos. Alguns meses depois, a Comissão de Constituição e Justiça do Senado ${ }^{12}$ aprovou a redução da maioridade penal de 18 para 16 anos. ${ }^{13}$

Como se observa, incorporada ao tema da manutenção da democracia, a questão do combate ao crime ganha positividade como peça do grande consenso presente na uniformização dos valores políticos, morais e sociais da sociedade brasileira atual. Mesmo a realidade demonstrando que maior repressão não diminui a criminalidade (ao contrário, abarrota as penitenciárias permitindo a proliferação de organizações criminosas), esse discurso ganha cada vez

${ }^{11}$ Em matéria veiculada no Jornal Folha de São Paulo. Edição do dia 18/02/2007.

${ }^{12}$ A Comissão aprovou no dia 26/04/2007, por 12 votos a 10, a PEC (Proposta de Emenda Constitucional) que reduz de 18 para 16 anos a maioridade penal no país. O texto, do senador Demóstenes Torres (DEM-GO), propõe a redução, mas estabelece o regime prisional somente para jovens menores de 18 anos e maiores de 16 que cometerem crimes hediondos. In: Folha de São Paulo - Caderno Cotidiano - Edição on line do dia 26/04/2007.

${ }^{13}$ Ressalta-se que por se tratar de emenda à Constituição, para virar lei, a proposta ainda deverá ser discutida amplamente e votada nas duas casas do Congresso Nacional. mais legitimidade e, de forma paradoxal, associa-se à defesa da democracia.

Merece, portanto, extrema atenção por parte da ciência a adoção, pelos recentes governos democráticos brasileiros, de uma política penal de exceção contrária às noções de democracia e cidadania e que coloca novamente a questão social como um caso de polícia.

Refletir criticamente sobre o assunto é essencial para o aprimoramento de uma sociedade civil crítica, participativa e capaz de exercer sua cidadania de forma coerente. É justamente essa competência cívica que o Estado Punitivo atual procura evitar.

\section{REFERÊNCIAS}

ATHAYDE, Celso. [et. al.]. Cabeça de Porco. Rio de Janeiro: Objetiva, 2005.

BAUMAN, Zygmunt. $O$ mal-estar da pósmodernidade. Rio de Janeiro: Jorge Zahar, 1998.

BAUMAN, Zygmunt. Globalização: as conseqüencias humanas. Rio de Janeiro: Jorge Zahar, 1999.

BAUMAN, Zygmunt. Comunidade: a busca por segurança no mundo atual. Rio de Janeiro: Jorge Zahar, 2003.

BATISTA, Nilo. Novas tendências do direito penal. Palestra proferida no Centro de Estudos Judiciários em 8 de maio de 2003a.

BATISTA, Nilo. Mídia e Sistema Penal no Capitalismo Tardio. In: Revista Brasileira de Ciências Criminais. (número especial). Ano 11, N. ${ }^{\circ}$ 42, Janeiro/Março, 2003 b.

BATISTA, Nilo. Prezada Senhora Viégas: o anteprojeto de reforma no sistema de penas. In: Discursos sediciosos. Crime, direito e sociedade. Rio de Janeiro, Ano 5, n. ${ }^{\circ} 9$ e 10 , 2000, p. 107.

BATISTA, Vera Malaguti. Autoritarismo e controle social no Brasil - Memória e medo. In: Revista Sem Terra. n. ${ }^{\circ}$ 10, 2001. 
BECK, Francis Rafael. Perspectivas de controle ao crime organizado e críticas à flexibilização de garantias. São Paulo: IBCCRIM, 2004.

CHRISTIE, Nils. Elementos de geografia penal. In: Discursos sediciosos. Crime, direito e sociedade. Rio de Janeiro, Ano 7, n. ${ }^{\circ} 11,1^{\circ}$ semestre de 2002.

FOUCAULT, Michel. Vigiar e punir: nascimento da prisão. 12.ed. Tradução de Lígia Vassallo. Petrópolis: Vozes, 1987.

GARAPON, Antoine. O juiz e a democracia: o guardião das promessas. 2.ed. Tradução de Maria Luiza de Carvalho. Rio de Janeiro: Revan, 2001.

GARLAND, David. As contradições da "sociedade punitiva": o caso britânico. In: Revista de Sociologia e Política, n. ${ }^{\circ} 13,59-80$, nov., Curitiba, 1999.

GARLAND, David. The culture of control: crime and social order in contemporary society. Chicago, University of Chicago Press, 2001.

JACOBS, Claudia Silva. Para órgão da ONU, situação no sistema prisional é grave. $B B C$ Brasil.COM. Brasília, 5 de agosto de 2004. Disponível em www.bbc.co.uk/portuguese/ reporterbbc/story/2004. Acessado em 20 de julho de 2007

LAMOUNIER, Bolívar e SOUZA, Amaury de. O futuro da democracia: cenários políticoinstitucionais até 2022. In: Revista Estudos Avançados. Vol. 20, n. ${ }^{\circ}$ 56, p 44-60, 2006.
OLIVEN, Rubem George. Chame o ladrão: as vítimas da violência no Brasil. In: BOSCHI, R. R. (Org.). Violência e cidade. Rio de Janeiro: Zahar, 1981.p.21-28. (Série Debates Urbanos). PAIXÃO, Antonio Luiz; BEATO, Cláudio C. Crimes, Vítimas e Policiais. In: Revista de Sociologia da USP. Vol. 9, n. ${ }^{\circ} 1$, Maio, 1997.

PASTANA, Debora Regina. Cultura do medo: reflexões sobre violência, controle social e cidadania no Brasil. São Paulo: Método, 2003.

SALLA Fernando; GAUTO Maitê; ALVAREZ Marcos César. A contribuição de David Garland: a sociologia da punição. In: Revista Tempo Social. Vol. 18, n. ${ }^{\circ}$ 1. São Paulo, Junho, 2006.

SOUZA, Luís Antônio Francisco de. Obsessão securitária e a cultura do controle. In: Revista de Sociologia e Política. N. ${ }^{\circ}$ 20, Curitiba, 2003 b.

TEIXEIRA, Alessandra. BORDINI, Eliana Blumer Trindade. "Decisões judiciais da Vara das Execuções Criminais: punindo sempre mais". In: São Paulo em Perspectiva. Vol. 18, n. ${ }^{\circ}$ 1, São Paulo, Janeiro, 2004.

WACQUANT, Loïc. As Prisões da Miséria. Rio de Janeiro: Jorge Zahar Editor, 2001a.

WACQUANT, Loïc. Punir os pobres: a nova gestão da miséria nos EUA. Rio de Janeiro: Editora Freitas Bastos, 2001b. 